\title{
Does an early rural life influence selected health-related parameters of female university students?
}

\author{
Martyna Zurawiecka',A-F, Katarzyna Klis ${ }^{1,2, A-F}$, Agnieszka Suder ${ }^{3, B-C, E-F}$, Edyta Suliga ${ }^{4, B-C, E-F}$, \\ Beata Borowska-Struginska ${ }^{5, B-C, E-F}$, Iwona Teul ${ }^{6, B-C, E-F}$, Iwona Wronka ${ }^{1, A-F}$ \\ ${ }^{1}$ Department of Anthropology, Institute of Zoology and Biomedical Research, Jagiellonian University, Krakow, Poland \\ 2 Department of Human Biology, University of Wroclaw, Poland \\ ${ }^{3}$ Department of Anatomy, University of Physical Education, Krakow, Poland \\ ${ }^{4}$ Department for the Prevention of Alimentary Tract Diseases, Institute of Nursing and Obstetrics, Faculty of Medicine \\ and Health Sciences, Jan Kochanowski University, Kielce, Poland \\ ${ }^{5}$ Department of Anthropology, Faculty of Biology and Environmental Protection, University of Lodz, Poland \\ ${ }^{6}$ Department of Anatomy, Pomeranian Medical University, Szczecin, Poland \\ A - Research concept and design, B - Collection and/or assembly of data, C - Data analysis and interpretation, \\ $D$ - Writing the article, E-Critical revision of the article, F- Final approval of article
}

Zurawiecka M, Klis K, Suder A, Suliga E, Borowska-Struginska B, Teul I, Wronka I. Does an early rural life influence selected health-related parameters of female university students? Ann Agric Environ Med. 2019; 26(2): 322-328. doi: 10.26444/aaem/93746

\begin{abstract}
Objective. The aim of the study was to define whether in a group of young women the place of residence in their childhood and adolescence, as well as moving from a rural to an urban area, have affected their biological condition.

Materials and method. The data were obtained from 1,305 unmarried and childless women aged 18-25. The respondents were university students. Each person's height, weight and waist circumference were measured, and the BMI, WHR, and $\mathrm{WHtR}$ indices were calculated. A survey was used to collect data on the females' socio-economic status, their health condition and course of menstruation cycle.

Results. In the whole sample, apart from WHR, there was no significant difference in anthropometric characteristics depending on the urbanization degree of the place of residence before commencing studies. In comparing the two groups of women, changing place of residence from a village to a city and from a city to another city, more differences were visible. Women of rural origin presented significantly higher values of BMI, waist circumference and WHtR than those from the city. They were also more frequently characterized by overweight and abdominal obesity. The women from other cities were characterized by underweight and too low amount of abdominal adipose tissue. Health problems were found in both groups. Students of rural origin more rarely declared changes in body weight and health condition after beginning studies. Students of urban origin were more often affected by sleeping problems and spine pains.

Conclusions. The results of the study do not indicate that a change of place of residence has a stronger effect on the biological condition of rural women than their urban peers.
\end{abstract}

Key words

obesity, rural-urban disparities, underweight, heath status

\section{INTRODUCTION}

Rural-urban disparities in child development as well as child and adult health status have been observed in a large number of populations in different periods of time. ${ }^{1,2}$ Data from Europe show that in the $19^{\text {th }}$ century the city dwellers were characterized by delayed growth during childhood and worse health status in comparison to the inhabitants of rural regions [1]. There were several causes for the relationship, from a limited access to fresh food in a city environment to the faster spread of diseases connected with higher population density [2]. The appearance of protective vaccinations, better possibilities of storing and transporting food, development of health care and limiting child employment resulted in a significant improvement in living conditions in cities [3]. A

Address for correspondence: Iwona Wronka, Department of Anthropology, Institute of Zoology and Biomedical Research, Jagiellonian University, Cracow, Poland, Gronostajowa 9, 30-087 Kraków, Poland

e-mail: iwona.wronka@uj.edu.pl

Received: 09.05.2018; accepted: 24.07.2018; first published:03.08.2018 reverse gradient was observed and a faster rate of biological development and better health status were registered among urban rather than rural populations [4-8]. Data from different countries, including Poland, indicated differences in the age at sexual maturation [9-11], body size and proportions [12$14]$ and physical fitness $[9,15]$, as well as in health condition [16-20].

Differences in the biological condition between urban and rural populations result from different living conditions and lifestyle maintained for years, and depending on the degree of urbanization, especially: sanitary conditions, access to health care, nutrition of children and their physical workload. However, the data obtained during researches conducted since the 1990s show that living conditions and lifestyle are levelling out as a result of intensive activities within social policies and health care improvements implemented in Poland and other European countries in recent years [21, 22]. In the USA and Canada, as well as in most Western Europe countries during the period of 1950-1980, the differences in body size between rural and urban inhabitants, both in 
children and adults, practically disappeared [23]. However, there are new factors connected with the level of urbanization that significantly affect the biological condition. For example, in a city environment, the level of air pollution is higher and access to shops with unhealthy goods and fast food restaurants is easier.

For many years, cities have offered better living conditions, and still today, many people find cities more attractive places to live; they also offer better possibilities to find a well-paid job. Therefore, it is not surprising that the most common type of migration that has ever occurred in the history of mankind has been the migration from villages to cities. It is estimated that currently more than 50 percent of people worldwide live in urban areas. Several studies have compared people changing their place of residence from rural to urban and people staying in villages, the results of which show the better conditions of the migrants [24-29]. The studies also took into consideration remote results of migration indicating differences in the development of the children of migrants and non-migrants [27-29]. However, no studies have been undertaken on the influence of changing the rural environment to the urban on eco-sensitive and rapid changing features, e.g. weight or selected parameters of state of health and acclimatisation to life in the city.

\section{OBJECTIVE}

The main aim of the present work was to define whether in a group of young women the place of residence in childhood and adolescence,as well as moving from rural to urban areas,had affected their health status. Body measurements and selected elements connected with health condition in female students who used to live in the country before their studies were compared to students who had always lived in the city. Due to the fact that the tests included only students, it can be claimed that all the surveyed were exposed to the same environmental factors connected with their professional situation. The analysis also took into account their present place of residence focusing on people living in different places than their parents. In Poland, the most common age to begin studies is 19 years, just after attaining adulthood. Therefore, the beginning of studies is the time one begins to be independent, rents a flat and shapes one's own lifestyle. However, because of low average earnings and the high costs of renting a flat, many young people in Poland decide to find a university near their birthplace and continue to live with their parents during studies.

Apart from features frequently analysed in researches on biological differences in urban and rural inhabitants, such as: body height, Body Mass Index (BMI), occurrence of improper body weight, abdominal obesity, and age of menarche, this study also includes other parameters: disorders of menstrual cycle, frequency of upper respiratory tract infections, headaches, spine pains, insomnia or changes in weight, and general health status that appeared after the beginning of studies.

\section{MATERIALS AND METHOD}

The study utilises data obtained from 1,305 unmarried and childless women aged $18-25(19.98 \pm 1.34)$. The median age was 20 years. The research group consisted of students from universities in Poland: Jagiellonian University in Krakow $(\mathrm{N}=406,31.11 \%)$, University of Physical Education in Krakow, students of Rehabilitation and Cosmetology ( $=200,15.33 \%)$ at the Jan Kochanowski University in Kielce (N=189, 14.49\%), University of $\operatorname{Lodz}(\mathrm{N}=308,23.60 \%)$, and the Pomeranian Medical University in Szczecin (N=202, 15.47\%). They had started studying at least one year before the survey. None of the surveyed women declared prevalence of chronic diseases, apart from allergies. The researches were conducted in April and May 2016. The study protocol was approved by the Ethics Committee of Jagiellonian University in Krakow (Opinion No. 122.61.20.47.2016). The data were collected following the ethical principles stated in the Declaration of Helsinki.

Measurements of body weight were performed with the use of an electronic scale (accuracy to $0.5 \mathrm{~kg}$ ), body height with an anthropometer (accuracy to $1 \mathrm{~mm}$ ), waist and hip circumference with a metric tape (accuracy to $1 \mathrm{~cm}$ ). During the measurements, the examined were wearing light clothes without shoes. All the measurements were performed by the authors of the study, following the current anthropometric standards.

The following indices were also calculated: Body Mass Index (BMI), Waist to Hip ratio (WHR) and Waist to Height Ratio (WHtR). On the basis of BMI, 4 categories were differentiated applying WHO recommendations: underweight (BMI <18.50), normal (18.50-24.99), overweight (25.00-29.99) and obesity (>30.00). The waist circumference measurement was used to define the abdominal type of obesity. According to the guidelines, the correct value was accepted at the level of $80 \mathrm{~cm}$ and below. Presence of excessive adipose tissue in the central region was also assessed based on WHR and WHtR indices. The following categories were differentiated: no obesity - WHR $<0.8$, obesity occurrence - WHR $\geq 0.8$. WHtR was applied to distinguish 4 categories. The amount of fat in the abdominal region was estimated as being too low at the index values not exceeding 0.4 , correct for the values range $0.41-0.50$, increased within $0.51-0.60$. Values of 0.60 and above were classified as abdominal obesity. Categories of WHtR were created following set guidelines (Ashwell and Gibson, 2009) [30].

A survey was used to collect data on the examined females' socio-economic status, their health condition and the course of menstruation cycle. Socio-economic status was assessed with the use of commonly applied determinants of living conditions, such as: parents' education, number of siblings, and place of residence before studies. Place of residence was determined as a village or a city. Parents' education was divided into 3 categories: vocational, secondary and university, whereas the number of siblings as $0,1,2,3$ and more. The surveyed were also asked about their current place of residence which were placed in two categories: living together with parents or independently, with a partner or friends. The socioeconomic profile of the women is presented in Table 1.

The authors' questionnaire was applied to assess selected health-related problems. The questions concerning health condition referred to:

- health self-assessment (categories: perfect, very good, good, satisfactory, poor);

- a change of health condition in comparison to the time before studies (categories: much better, slightly better, similar, slightly worse, much worse);

- a change of body weight in comparison to the time before studies (categories: increased, decreased, stayed the same); 
Table 1. Socio-economic characteristics of subjects in relation to the place of living before studies

\begin{tabular}{|c|c|c|c|c|}
\hline & & $\begin{array}{c}\text { Urban } \\
(\mathrm{N}=757) \\
\mathrm{N}(\%)\end{array}$ & $\begin{array}{c}\text { Rural } \\
(\mathrm{N}=548) \\
\mathrm{N}(\%)\end{array}$ & $\mathrm{p}$-values \\
\hline \multirow{3}{*}{ Mother's education level } & vocational & $159(21.0)$ & $195(35.6)$ & \multirow{3}{*}{0.0009} \\
\hline & secondary & $253(33.4)$ & $237(43.2)$ & \\
\hline & university & $345(45.6)$ & $116(21.2)$ & \\
\hline \multirow{4}{*}{ Father's education level } & vocational & $248(32.8)$ & $270(49.3)$ & \multirow{4}{*}{0.0000} \\
\hline & secondary & $229(30.2)$ & $185(33.7)$ & \\
\hline & university & $256(33.8)$ & $81(14.8)$ & \\
\hline & missing values & $24(3.2)$ & $12(2.2)$ & \\
\hline \multirow{4}{*}{ Number of siblings } & 0 & $167(22.1)$ & $58(10.6)$ & \multirow{4}{*}{0.0005} \\
\hline & 1 & $383(50,6)$ & $240(43.8)$ & \\
\hline & 2 & $137(18.1)$ & $159(29.0)$ & \\
\hline & 3 and more & $70(9.2)$ & $91(16.6)$ & \\
\hline \multirow{3}{*}{ Socio-economic status } & low & $137(18.1)$ & $208(37.9)$ & \multirow{3}{*}{0.0008} \\
\hline & medium & $319(42.1)$ & $253(46.2)$ & \\
\hline & high & $301(39.8)$ & 87 (15.9) & \\
\hline
\end{tabular}

-values based on $\mathrm{Chi}^{2}$ test

Bold type - statistically significant difference

- regularity of menstruation cycle;

- appearance of menstruation pain (categories: painless, moderately painful, very painful);

- incidence rate of viral and bacterial diseases (categories: very often, a few times a year, once a year, more rarely than once a year);

- incidence rate of spine pains (categories: at least once a week, at least once a month, hardly ever, never;

- incidence rate of headaches (categories: at least once a week, at least once a month, hardly ever, never);

- problems with falling asleep (categories: often, sometimes, never);

- occurrence of allergic diseases.

The questionnaire was created on the basis of formerly conducted researches applying, among others, the SF-36 questionnaire which concerned health problems the students most frequently complained about. This was verified in pilot tests (results elaborated in an MA thesis, not published). Cronbach's Alpha Reliability Coefficient - 0.07901.

The collected material was divided into 4 groups:

1) women of city origin studying in the same city $(\mathrm{N}=353)$;

2) women of city origin studying in a different city $(\mathrm{N}=404)$;

3) women of rural origin women currently living and studying in a city (386);

4) women of rural origin currently living in a village, but studying in a city and commuting to their universities (162).

The second group included women who moved to a smaller or the same city as the one they lived in before studies. Only a few percent of them moved to a smaller city and were mainly those living in Warsaw before their studies.

The present study comprises analyses of the whole material considering division onto place of residence before studies (city-village), and for students who changed their place of residence, also taking into account the division onto place of residence before studies. The first and fourth groups were omitted in the analysis due to the low numerical strength of the fourth group, and the fact that the first group contained both students still living in their family homes and independently so that the group was not homogeneous and should be analysed as two separate groups.

Statistical methods. The statistical analysis utilised methods of descriptive statistics. The Shapiro-Wilk test was used to determine normality of distribution. All anthropometrical variables were normally distributed (BMI: $\mathrm{p}=0.061$, WC: $\mathrm{p}=0.068$, WHtR: $\mathrm{p}=0.079$, WHR: $\mathrm{p}=0.072$ ). The t-Student's test was applied to assess the significance of differences in variables of continuous type between rural-origin and urban-origin students. The $\mathrm{Chi}^{2}$ independence test was used to define significance of rural-urban differences between categorical variables.

The dependent variables were also modelled with univariate or logistic regression in order to adjust for socio-economics factors. Odds ratios (OR) and 95\% confidence intervals (CI) are presented.

Significance level was accepted at $\mathrm{p}<0.05$. All calculations were performed using a Statistica 10 software pack.

\section{RESULTS}

The data presented in Table 1 show differences in parents' education level and the number of children in a family, depending on the urbanization degree of the place of residence before studies. Before the beginning of studies, 757 women $(58.0 \%)$ lived in a city and $548(42.0 \%)$ in the country. The parents of students of urban origin completed university education much more frequently than those from rural areas. Students from cities had fewer brothers and sisters than their peers from the country. Additionally, socio-economic status (SES) was established on the basis of the first factor scores derived from principal component analysis (PCA). The eigenvalue of the analysed factor reached 2.85 and explained $43.6 \%$ of common variation in SES. Three groups of SES (low, medium and high) were based on the tertiles. No significant difference was found in the age of rural and urban women ( $\mathrm{p}$-values based on Mann-Whitney U test:0.5670). The mean age of surveyed urban women was $20.11 \pm 1.42$, median -20 , mean age of rural women $-19.86 \pm 1.27$, median -20 .

Although there were significant differences in the socioeconomic factors in relation to the level of urbanization of the place of residence before study (Tab. 1), the results did not show rural-urban differences in body sizes, apart from WHR which demonstrated higher values in rural origin females (Tab. 2). No differences occurred after adjusting for socio-economic status (Tab. 2).

The degree of urbanization of the place of residence before studies also did not affect the prevalence of improper body weight and abdominal obesity (Tab. 3). The women of urban origin more frequently featured a too low amount of adipose tissue in the abdominal region. Analysis of the selected parameters connected with health condition showed significant differences in the prevalence of spine pains, viral and incidence rate of bacterial diseases, and sleeping problems. The the women of rural origin more rarely declared frequent spine pains, viral and bacterial diseases, and sleeping problems, compared to their urban peers (Tab. 3). 
Table 2. Anthropometric characteristics of subjects in relation to the place of living before studies (total sample $\mathrm{N}=1305)$ ).

\begin{tabular}{lcccc}
\hline & $\begin{array}{c}\text { Urban } \\
(\mathrm{N}=757) \\
\text { mean } \pm \text { SD }\end{array}$ & $\begin{array}{c}\text { Rural } \\
(\mathrm{N}=548) \\
\text { mean } \pm \mathrm{SD}\end{array}$ & p-values & p-values \\
\hline $\begin{array}{l}\text { Body Mass Index }\left[\mathrm{kg} / \mathrm{m}^{2}\right] \\
\text { (BMI) }\end{array}$ & $21.61 \pm 3.19$ & $22.16 \pm 8.80$ & 0.1106 & 0.1199 \\
\hline Waist circumference $[\mathrm{cm}]$ & $71.49 \pm 9.01$ & $72.17 \pm 9.13$ & 0.0768 & 0.1663 \\
\hline $\begin{array}{l}\text { Waist to Height Ratio }) \\
\text { (WHtR) }\end{array}$ & $0.43 \pm 0.05$ & $0.44 \pm 0.05$ & 0.1922 & 0.1838 \\
\hline $\begin{array}{l}\text { Waist to Hip Ratio } \\
\text { (WHR) }\end{array}$ & $0.75 \pm 0.06$ & $0.76 \pm 0.07$ & $\mathbf{0 . 0 3 7 0}$ & $\mathbf{0 . 0 9 8 7}$ \\
\hline
\end{tabular}

p-values' based on $t$-Student test

$p$-values ${ }^{2}$ based on univariate regression, adjusted for socioeconomic status Bold type - statistically significant difference

Table 3. Prevalence of selected health problem in relation to the place of living before studies (total sample $\mathrm{N}=1305$ ).

\begin{tabular}{|c|c|c|c|c|}
\hline & & $\begin{array}{c}\text { Urban } \\
(\mathrm{N}=757) \\
\mathrm{N}(\%)\end{array}$ & $\begin{array}{c}\text { Rural } \\
(\mathrm{N}=548) \\
\mathrm{N}(\%)\end{array}$ & $\mathrm{p}$ - values \\
\hline \multirow{4}{*}{$\begin{array}{l}\text { Body Mass Index } \\
\text { (BMI) }\end{array}$} & $<18.50$ & $104(13.7)$ & $58(10.6)$ & \multirow{4}{*}{0.1983} \\
\hline & $18.50-24.99$ & $553(73.1)$ & $404(73.7)$ & \\
\hline & $25.00-29.99$ & $88(11.6)$ & $72(13.1)$ & \\
\hline & $\geq 30$ & $12(1.6)$ & $14(2.6)$ & \\
\hline \multirow{2}{*}{ Waist circumference } & $\leq 80 \mathrm{~cm}$ & $645(85.2)$ & $459(83.8)$ & \multirow{2}{*}{0.1148} \\
\hline & $>80 \mathrm{~cm}$ & $112(14.8)$ & $89(16.3)$ & \\
\hline \multirow{4}{*}{$\begin{array}{l}\text { Waist to Height Ratio } \\
\text { (WHtR) }\end{array}$} & $<0.4$ & $266(35.1)$ & $149(27.2$ & \multirow{4}{*}{0.0211} \\
\hline & $0.4-0.5$ & $410(54.2)$ & $339(61.9)$ & \\
\hline & $0.5-0.6$ & $73(9.6)$ & $55(10.0)$ & \\
\hline & $>0.6$ & $8(1.1)$ & $5(0.9)$ & \\
\hline \multirow{2}{*}{$\begin{array}{l}\text { Waist to Hip Ratio } \\
\text { (WHR) }\end{array}$} & $\leq 0.8$ & $633(83.6)$ & $436(79.6)$ & \multirow[t]{2}{*}{0.1215} \\
\hline & $>0.8$ & $124(16.4)$ & $112(20.4)$ & \\
\hline \multirow{4}{*}{ Headache } & once a week & $159(21.0)$ & $104(19.0)$ & \multirow{4}{*}{0.0966} \\
\hline & once a month & $223(29.5)$ & $146(26.6)$ & \\
\hline & very rarely & $213(28.1)$ & $188(34.3)$ & \\
\hline & never & $162(21.4)$ & $110(20.1)$ & \\
\hline \multirow{4}{*}{ Spine pain } & once a week & $174(23.0)$ & $80(14.6)$ & \multirow{4}{*}{0.0001} \\
\hline & once a month & $214(28.3)$ & $155(28.3)$ & \\
\hline & very rarely & $271(35.8)$ & $242(44.1)$ & \\
\hline & never & $98(12.9)$ & $71(13.0)$ & \\
\hline \multirow{3}{*}{$\begin{array}{l}\text { Viral and bacterial } \\
\text { diseases }\end{array}$} & very often & 375 (49.5) & $225(41.1)$ & \multirow{3}{*}{0.0097} \\
\hline & once a year & $246(32.5)$ & $205(37.4)$ & \\
\hline & very rarely & $136(18.0)$ & $118(21.5)$ & \\
\hline \multirow{3}{*}{ Sleeping problems } & very often & $110(14.5)$ & $40(7.3)$ & \multirow{3}{*}{0.0000} \\
\hline & sometimes & 393 (51.9) & $273(49.8)$ & \\
\hline & never & $254(33.6)$ & $235(42.9)$ & \\
\hline \multirow{3}{*}{ Health condition } & good and very good & $278(36.7)$ & $228(41.6)$ & \multirow{3}{*}{0.1321} \\
\hline & average & $392(51.8)$ & $270(49.3)$ & \\
\hline & poor & $87(11.5)$ & $50(9.1)$ & \\
\hline \multirow{3}{*}{$\begin{array}{l}\text { Health condition } \\
\text { changes }\end{array}$} & better & $68(9.0)$ & $39(7.1)$ & \multirow{3}{*}{0.4407} \\
\hline & no change & $525(69.3)$ & $393(71.7)$ & \\
\hline & worse & $164(21.7)$ & $116(21.2)$ & \\
\hline \multirow{2}{*}{$\begin{array}{l}\text { Menstrual cycle } \\
\text { regularity }\end{array}$} & regular & $570(75.3)$ & 394 (71.9) & \multirow{2}{*}{0.1677} \\
\hline & irregular & $187(24.7)$ & $154(28.1)$ & \\
\hline \multirow{3}{*}{ Body weight change } & decrease & $225(29.7)$ & $153(27.9)$ & \multirow{3}{*}{0.1930} \\
\hline & increase & $170(22.5)$ & $112(20.5)$ & \\
\hline & no change & $362(47.8)$ & $283(51.6)$ & \\
\hline
\end{tabular}

p-values based on $\mathrm{Chi}^{2}$ test

Bold type - statistically significant difference
The risks of selected health problems in rural students compared to the urban were also evaluated by logistic regression, adjusted for socio-economic status. The statistically significant differences were found for occurrence of WHtR below 0.4 (OR=0.67, 95\% CI: $0.42-0.94)$, occurrence of spine pain at least once a week $(\mathrm{OR}=0.60,95 \% \mathrm{CI}$ : 0.47 0.84 ), very frequent occurrence of viral and bacterial diseases (OR=0.70, 95\% CI: 0.57-0.88), very frequent occurrence of sleeping problems $(\mathrm{OR}=0.46,95 \% \mathrm{CI}$ : $0.30-0.61)$.

Some of the analysed features were strongly dependant on current living conditions. Another analysis included only the data of the women who studied outside their place of residence childhood and adolescent place of residence for a period of 12 months or more. Two groups were compared: students who had to change their place of residence due to beginning of studies, from a village to a city, and those who moved from one city to another. Students of rural origin presented significantly higher values of BMI, waist circumference and WHtR than their city peers (Tab. 4). Differences in BMI, waist circumference and WHtR between different community sizes remained significant after adjusting for socio-economic status (Tab. 4).

Table 4. Anthropometric characteristics of subjects in relation to the place of living before studies (groups of students who moved from villages or other cities $\mathrm{N}=790$ )

\begin{tabular}{lcccc}
\hline & $\begin{array}{c}\text { Moved from } \\
\text { other cities } \\
(\mathrm{N}=404) \\
(\mathrm{mean} \pm \mathrm{SD})\end{array}$ & $\begin{array}{c}\text { Moved from } \\
\text { rural area } \\
(\mathrm{N}=386)\end{array}$ & p-values \pm (m) & p-values \\
\hline $\begin{array}{l}\text { Body Mass Index }\left[\mathrm{kg} / \mathrm{m}^{2}\right] \\
(\mathrm{BMI})\end{array}$ & $21.50 \pm 3.28$ & $22.63 \pm 10.23$ & $\mathbf{0 . 0 2 2 1}$ & $\mathbf{0 . 0 3 6 7}$ \\
\hline Waist circumference $[\mathrm{cm}]$ & $71.13 \pm 9.06$ & $72.58 \pm 9.19$ & $\mathbf{0 . 0 3 6 8}$ & $\mathbf{0 . 0 3 2 2}$ \\
\hline $\begin{array}{l}\text { Waist to Height Ratio } \\
\text { (WHtR) }\end{array}$ & $0.43 \pm 0.05$ & $0.44 \pm 0.05$ & $\mathbf{0 . 0 2 9 8}$ & $\mathbf{0 . 0 3 0 1}$ \\
\hline $\begin{array}{l}\text { Waist to Hip Ratio } \\
\text { (WHR) }\end{array}$ & $0.75 \pm 0.06$ & $0.75 \pm 0.07$ & $\mathbf{0 . 0 0 2 8}$ & $\mathbf{0 . 0 0 7 2}$ \\
\hline
\end{tabular}

$p$-values' based on $t$-Student test

$p$-values ${ }^{2}$ based on univariate regression, adjusted for socioeconomic status

Bold type - statistically significant difference

Students who had moved from villages to cities were more frequently characterized by overweight and abdominal obesity, whereas students moving from other cities by underweight and a too low amount of abdominal adipose tissue (Tab. 5). Students who had moved from other cities more often claimed that their body weight decreased after the beginning of studies. Self-assessment concerning health condition, changes of health state after the beginning of studies, as well as the rate of incidence of viral and bacterial diseases were similar in both groups (Tab. 5). The differences were connected with spine pains and sleeping problems. In all cases, a frequent occurrence of the discomforts was declared by far fewer students who changed their place of residence from the country to the city (Tab. 5).

Students who had to change their place of residence from a city to another city due to the beginning of studies, more often confirmed health condition changes than those who moved from a village to a city (Tab. 5).

Statistically significant differences (adjusted for socioeconomic status) in the risk of selected health problems were found for the occurrence of underweight $(\mathrm{OR}=0.62,95 \% \mathrm{CI}$ : $0.39-0.90)$ and overweight $(\mathrm{OR}=1.35,95 \% \mathrm{CI}$ : $0.89-1.55)$, 
Table 5. Prevalence of selected health problems in relation to the place of living before studies (groups of students who moved from villages or other cities $\mathrm{N}=790$ )

\begin{tabular}{|c|c|c|c|c|}
\hline & & $\begin{array}{c}\text { Moved } \\
\text { from other } \\
\text { cities } \\
(\mathrm{N}=404) \\
\mathrm{N}(\%)\end{array}$ & $\begin{array}{c}\text { Moved } \\
\text { from rural } \\
\text { areas } \\
(\mathrm{N}=386) \\
\mathrm{N}(\%)\end{array}$ & $p$-values \\
\hline \multirow{4}{*}{$\begin{array}{l}\text { Body Mass Index } \\
\text { (BMI) }\end{array}$} & $<18.50$ & $76(18.8)$ & $28(7.2)$ & \multirow{4}{*}{0.0009} \\
\hline & $18.50-24.99$ & $279(69.0)$ & 289 (74.9) & \\
\hline & $25.00-29.99$ & $41(10.2)$ & $59(15.3)$ & \\
\hline & $\geq 30$ & $8(2.0)$ & $10(2.6)$ & \\
\hline \multirow[t]{2}{*}{ Waist circumference } & $\leq 80 \mathrm{~cm}$ & $345(85.4)$ & $318(82.4)$ & \multirow[t]{2}{*}{0.1202} \\
\hline & $>80 \mathrm{~cm}$ & $59(14.6)$ & $68(17.6)$ & \\
\hline \multirow{4}{*}{$\begin{array}{l}\text { Waist to Height Ratio } \\
\text { (WHtR) }\end{array}$} & $<0.4$ & $141(34.9)$ & $94(24.3)$ & \multirow{4}{*}{0.0198} \\
\hline & $0.4-0.5$ & $212(52.5)$ & $245(63.5)$ & \\
\hline & $0.5-0.6$ & $45(11.1)$ & $43(11.1)$ & \\
\hline & $>0.6$ & $6(1.5)$ & $4(1.0)$ & \\
\hline \multirow{2}{*}{$\begin{array}{l}\text { Waist to Hip Ratio } \\
\text { (WHR) }\end{array}$} & $\leq 0.8$ & 338 (83.6) & $309(80.0)$ & \multirow{2}{*}{0.1426} \\
\hline & $>0.8$ & $66(16.4)$ & $77(20.00)$ & \\
\hline \multirow{4}{*}{ Headache } & once a week & $83(20.5)$ & $78(20.2)$ & \multirow{4}{*}{0.0837} \\
\hline & once a month & $117(29.0)$ & $96(24.9)$ & \\
\hline & very rarely & $118(29.2)$ & $135(35.0)$ & \\
\hline & never & $86(21.3)$ & $77(19.9)$ & \\
\hline \multirow{4}{*}{ Spine pain } & once a week & $87(21.5)$ & $43(11.1)$ & \multirow{4}{*}{0.0006} \\
\hline & once a month & $103(25.5)$ & $105(27.2)$ & \\
\hline & very rarely & $157(38.9)$ & $195(50.5)$ & \\
\hline & never & $57(14.1)$ & $43(11.1)$ & \\
\hline \multirow{3}{*}{$\begin{array}{l}\text { Viral and bacterial } \\
\text { diseases }\end{array}$} & very often & $182(45.0)$ & $154(39.9)$ & \multirow{3}{*}{0.1962} \\
\hline & once a year & $151(37.4)$ & $150(38.9)$ & \\
\hline & very rarely & 71 (17.6) & $82(21.2)$ & \\
\hline \multirow{3}{*}{ Sleeping problems } & very often & $53(13.1)$ & $28(7.3)$ & \multirow{3}{*}{0.0004} \\
\hline & sometimes & $207(51.2)$ & $195(50.5)$ & \\
\hline & never & $144(35.7)$ & $163(42.2)$ & \\
\hline \multirow{3}{*}{ Health condition } & good and very good & $164(40.6)$ & $146(37.8)$ & \multirow{3}{*}{0.1211} \\
\hline & average & $202(50.0)$ & $206(53.4)$ & \\
\hline & poor & $38(9.41)$ & $34(8.8)$ & \\
\hline \multirow{3}{*}{$\begin{array}{l}\text { Health condition } \\
\text { changes }\end{array}$} & better & $45(11.1)$ & $23(6.0)$ & \multirow{3}{*}{0.0100} \\
\hline & no change & $252(62.4)$ & $278(72.0)$ & \\
\hline & worse & $107(26.5)$ & $85(22.0)$ & \\
\hline \multirow{2}{*}{$\begin{array}{l}\text { Menstrual cycle } \\
\text { regularity }\end{array}$} & regular & $294(72.8)$ & $276(71.5)$ & \multirow{2}{*}{0.1523} \\
\hline & irregular & $110(27.2)$ & $110(28.5)$ & \\
\hline \multirow{3}{*}{ Body weight change } & decrease & $113(28.0)$ & $102(26.4)$ & 0.0277 \\
\hline & increase & $111(27.5)$ & $79(20.5)$ & \\
\hline & no change & $180(44.5)$ & $205(53.1)$ & \\
\hline
\end{tabular}

p-values based on $\mathrm{Ch}^{2}$ tes

Bold type - statistically significant difference

WHtR below $0.4(\mathrm{OR}=0.63,95 \% \mathrm{CI}: 0.37-0.92)$, spine pain at least once a week $(\mathrm{OR}=0.59,95 \% \mathrm{CI}$ : $0.42-0.86)$, very frequent occurrence of viral and bacterial diseases $(\mathrm{OR}=0.68,95 \% \mathrm{CI}$ : $0.53-0.86)$, very frequent occurrence of sleeping problems $(\mathrm{OR}=0.47,95 \% \mathrm{CI}: 0.30-0.60)$, and body weight changes $(\mathrm{OR}=0.69,95 \%$ CI: 0.41-0.98).

\section{DISCUSSION}

The degree of urbanization of the place of residence was tightly connected with living conditions and lifestyle, which is reflected in the development rate and different forming of biological features in other life phases. Social distances in growing up and maturation are believed to be a good measure of the inequalities of living conditions existing in each society. However, information on children and the youth development from highly developed countries shows that despite sometimes remarkable inequalities in education, professional qualifications or earnings, the differences in biological features may disappear $[15,22,31]$. This probably results from the fact that after achieving a proper high level of wealth, accompanied by proper social policies of the State, the inequalities in social and material situation of families, although still present, no longer differentiate biological development. If the living conditions are generally good, their further improvement or slight worsening do not affect the development rate [32].

Studies conducted in Poland demonstrate that recently the rural-urban distances in biological development have significantly decreased or even disappeared [21,33]. The state of biological classlessness has also been observed in past decades in Norway and Sweden, where the achieved standard of living allowed the erasure of differences in the somatic development of children from socially different environments [34-35]. Analogous results have been obtained in the presented study.

Despite existing differences in parents' education and size of the family between urban and rural women, no significant differences were found between the two groups in relation to features shaped in childhood and adolescence: body height and age of menarche. Also, no differences were noticed concerning fatness, which is a feature strongly dependant on current living conditions, whereas differences were observed in relation to selected parameters connected with health condition. The scientific literature data on the regions of Poland indicate continuing differences referring to fatness and health condition between adult inhabitants of cities and villages [36-39]. A similar situation takes place in other countries [40-44].

The differences between city and village are mainly explained by differentiation of factors of physical, socioeconomic and cultural environments, as well as pro- and anti-health behaviour. Another hypothesis, the so called hypothesis of drift, claims that urbanization differentiation of health condition is connected with direct or indirect selective migration of people from one environment to another. According to this hypothesis, the place of residence is changed only by people characterized by a proper health condition. Migrants usually feature a better biological condition than non-migrants [16. 24-26]. Only in the oldest age groups the place of residence is changed by those characterised by a worse health condition. It can be assumed that this is connected with a better access to health care or closer distance to other relatives who can be helpful with everyday household chores [16].

The presented study included only students which can be viewed as both an advantage and a disadvantage. Studies in Poland are free of charge and a lot of people from different environments attend universities; however, those from the poorest families generally do not continue their education 
after the obligatory level. Therefore, a group of students is not fully representative for the whole of society. Yet, due to the fact that only students took part in the study, it was possible to obtain a homogeneous group in relation to an influence of factors connected with work environment. Additionally, as those studied had been living in a city for a relatively short time, the authors focused on features strongly dependant on current living conditions, and attempted to assess whether women from different environments acclimatized to living in a city at the same level.

It was checked how migration from villages to cities affected selected biological features and health condition. Comparing migrants from the country to city migrants it could be observed that the former more frequently featured overweight and obesity, whereas in the second group there were more cases of underweight and too low amount of adipose tissue in the region of the waist. This could be explained by the fact that a tendency to follow an ideal, a very slim silhouette created in the media is more common among the girls from cities [45]. In this study, women from cities much more frequently declared a change in body weight, both increase and decrease, than women from the country. It was observed in the whole group and in the group of women who studied in a different place than their previous place of residence before entering university.

Comparing selected parameters of health condition depending on the degree of urbanization of the place of before studies, it was found that women from cities were frequently affected by spine pains, viral and bacterial diseases, and sleeping problems. In the group of migrants, more frequent spine pains and sleeping problems were observed in students from cities. The last result is rather surprising as it could be expected that sleeping problems would occur in women from the country who are not used to continuous noise and light pollution. It might be connected with the time of being exposed to factors disturbing sleep that is much longer in urban women. This conclusion is confirmed by the fact that the tendency to more frequent sleeping problems in women from cities was observed, both for the whole material and in the group of migrants.

Comparisons of the two groups of women changing their place of residence from a village to a city and from a city to another city, showed that health problems were found in both groups. Students of rural origin had a tendency to obesity and the urban ones were often underweight. Rural origin students more rarely declared changes in body weight and health condition after the beginning of studies. This can be caused by the more conservative attitudes of villagers, and subsequently lower tendency to change their lifestyle connected with changing their place of residence. Whereas, urban origin students were more often affected by sleeping problems and spine pains.

A low number of women living in the country during their studies did not allow their inclusion in the second phases of the analysis. Also, women studying in their home town were excluded from the phase as their group comprised both students living in their family homes and independently. Leaving parents is often connected with a change in lifestyle, especially regarding being less careful about a proper diet; therefore this factor should not be omitted. The analysis included only women who moved to another place to study enabled obtaining a homogeneous group of similar current lifestyle and living conditions. However, a more complete analysis of the issue requires conducting further research in the future also comprising women who did not change their place of residence during their studies.

A study limitation is also the fact that the subjects were not selected randomly. The examinations began at the Jagiellonian University in Krakow after which the subsequent universities were chosen randomly, but from a limited group where the technical conditions allowed performing the tests (presence of an anthropologist who could take part in the tests, consent of the unit head to perform tests, a possibility to do research without disturbing didactic classes). However, currently, each university in Poland has students from all over the country and, for instance, at the Jagiellonian University there were fewer people from Krakow than from other places. The fact that studying in Poland is free of charge eliminates the selection of students because of their financial status. Therefore, the examined group can be assumed to be representative for the population of Polish female students.

\section{CONCLUSIONS}

The results obtained in this study do not indicate that a change of place of residence has a stronger effect on biological condition of rural women than their urban peers. In both groups, health problem occurred; however, the health and nutritional status seemed to be slightly more stable in students who had to change their place of residence from a village to a city due to begin their studies, and those who moved from a city to another city.

\section{REFERENCES}

1. Bogin B. Patterns of Human Growth. 2nd ed. Cambridge University Press, 1999.

2. Verheij RA. Explaining urban-rural variations in health: a review of interactions between individual and environment. Soc Sci Med. 1996; 42: 923-935.

3. Meredith HV. Comparative findings of body size of children and youths living at urban and rural areas. Growth 1979; 43: 95-104.

4. Avan BI, Kirkwood B. Role of neighborhoods in child growth and development: Does 'place' matter? Soc Sci Med. 2010; 71: 102-109.

5. Bergman-Markovic B, Vrdoljak D, Kranjcevic K, Vucak J, Kern J, Bielen I, Ivezic-Lalic D, Katic M, Reiner Z. Continental-Mediterranean and rural-urban differences in cardiovascular risk factors in Croatian population. Croat Med J. 2011; 52: 566-575.

6. Bruner MW, Lawson J, Pickett W, Boyce W, Janssen I. Rural Canadian adolescents are more likely to be obese compared with urban adolescents. Int J Pediat Obes. 2008; 3: 205-211.

7. Floud R, Watcher KW, Glregory AS. Height, health and history: nutritional status in Britain, 1750-1980. Cambridge: Cambridge University Press, 1990.

8. Gyenis G, Joubert K. Socioeconomic determinants of anthropometric trends among Hungarian youth. Econ Hum Biol. 2004; 2: 321-333.

9. Eiben OG, Barabas A, Nemeth A. Comparison of growth, maturation, and physical fitness of Hungarian urban and rural boys and girls. J Hum Ecol. 2005; 17: 93-100.

10. Hulanicka B, Brajczewski C, Jedlińska W, Sławiński T, Waliszko A. City, Town, Villages. Growth of children in Poland in 1988. Wroclaw: Monographies of the Institute of Anthropology Polish Academy of Sciences, 1990.

11. Popławska H, Wilczewski A, Dmitruk A, Hołub W. The timing of sexual maturation among boys and girls in eastern Poland, 1980-2000: A rural-urban comparison. Econ Hum Biol. 2013; 11: 221-226.

12. Krzyzanowska M, Umławska W. The relationship of Polish students' height, weight and BMI with some socioeconomic variables. J Biosoc Sci. 2010; 42: 643-652. 
13. Mascie-Taylor CGN, Goto R. Human variation and body mass index: A review of the universality of BMI cut-offs, gender and urban-rural differences, and secular changes. J Physiol Anthropol. 2007; 26: 109-112.

14. Pena Reyes ME, Tan SK, Malina RM. Urban-rural contrasts in the physical fitness of school children in Oaxaca, Mexico. Am J Hum Biol. 2003; 15: 800-813.

15. Ara I, Moreno LA, Leiva MT, Gutinm B, Casajus JA. Adiposity, physical activity, and physical fitness among children from Aragon, Spain. Obes. 2007; 15: 1918-1924.

16. Lipowicz A. Disparities in health status between rural and urban adult males in Lower Silesia, Poland. Anthropol Anz. 2015; 72: 13-25.

17. Morgan A. A national call to action: CDC's 2001 urban and rural health chartbook. J Rural Health 2002; 18: 382-383.

18. Suder A, Chrzanowska M. (2015): Risk factors of abdominal obesity in children and adolescents from Cracow, Poland (1983-2000). J Biosoc Sci. 2015; 47: 203-219.

19. Suder A, Janusz M, Jagielski P, Głodzik J, Pałka T, Cisoń T, Pilch W. (2015): Prevalence and risk factors of abdominal obesity in Polish rural children. Homo 2015; 66: 357-368.

20. Wilmanska J, Bien B, Wojszel B. Hypertension in the advanced old aged: prevalence and treatment in comparative urban and rural survey. Przeglad Lek. 2002, 59: 252-255.

21. Koziel S, Nowak-Stawarz N, Gomula A. Antropologiczne badania dzieci i młodzieży w Polsce w latach 1966-2012. Zmiany sekularne i zróżnicowanie społeczne. Wroclaw: Wydawnictwo Aboretum, 2014.

22. Marrodan MD, Mesa MS, Aréchiga J, Pérez-Magdaleno A. Trend in menarcheal age in Spain, rural and urban comparison during a recent period. Ann Hum Biol. 2000; 27: 313-319.

23. Eveleth P, Tanner J. Worldwide variation in human growth. New York: Cambridge University Press, 1990.

24. Benthham G. Migration and morbidity: implications for geographical studies of diseases. Soc Sci Med. 1998; 26: 49-54.

25. Szklarska A, Lipowicz A, Lopuszanska M, Bielicki T, Koziel S. Biological condition of adult migrants and nonmigrants in Wroclaw, Poland. Am J Hum Biol. 2008; 20: 139-145.

26. Verheij RA, van de Mheen HD, de Bakker DH, Groenewegen PP, Mackenbach JP. (1998): Urban-rural variations in health in The Netherlands: does selective migration plays a part? J Epidemiol Community Health 1998; 52: 172-181.

27. Gomula A, Koziel S. Post-migration adaptation and age at menarche in the second generation of migrants. Anthropol Anz. 2015; 72: 245-255.

28. Kolodziej H, Szklarska A, Malina, R. Young adult height of offspring born to rural-to-urban migrant parents and urban-born parents. Am J Hum Biol. 2001; 13: 30-34.

29. Krstevska-Konstantinova M, Charlier C, Craen M, Du Caju M, Heinrichs C, De Beaufort C, Plomteux G, Bourguignon JP. Sexual precocity after immigration from developing countries to Belgium: evidence of previous exposure to organochlorine pesticides. Hum Reprod. 2001; 16: 1020-1026.
30. Ashwell M, Gibson S. Waist to height ratio is a simple and effective obesity screening tool for cardiovascular risk factors: analysis of data from the British National Diet and Nutrition Survey of adults aged 19 to 64 years. Obes Fact. 2009; 2: 97-103.

31. Padez C, Rocha MA. Age at menarche in Coimbra (Portugal) school girls: a note on the secular change. Ann Hum Biol. 2003; 3: 622-632.

32. Bielicki T. Growth as an indicator of social inequalities. in "The Cambridge Encyclopedia of Human Growth and Development" ed. S. J. Ulijaszek, F.E. Johnston, M.A. Preece, Cambridge University Press 1998; pp. $54-57$.

33. Gurzkowska B, Kułaga Z, Litwin M, Grajda A, Świąder A, Kułaga K, Góźdź M. Wojtyło M. The relationship between selected socioeconomic factors and basic anthropometric parameters of school-aged children and adolescents in Poland. Eur J Pediatr. 2014; 173:45-52.

34. Brundtland GH, Liestol K, Walloe L. Height, weight and menarcheal age of Oslo schoolchildren during the last 60 years. Ann Hum Biol. 1980; 7: 307-322.

35. Cernerud L. Are there still social inequalities in height and body mass index of Stockholm children? J Pub Health 1994; 22: 161-165.

36. Jarosz M, Rychlik E. Overweight and obesity among adults in Poland, 1983-2005. Advanc Med Sci. 2008; 53: 158-166.

37. Maniecka-Bryła I, Pikala M, Bryła M. Health inequalities among rural and urban inhabitants of Łódź Province, Poland. Ann Agric Environ Med. 2012; 19: 723-731.

38. Masiak J, Kuśpit M, Surtel W, Jarosz M. Stress, coping styles and personality tendencies of medical students of urban and rural origin. Ann Agric Environ Med. 2014; 21: 189-193.

39. Wronka I, Kliś K, Jarzębak K. Association of allergic rhinitis in female university students with socio-economic factors and markers of estrogens levels. Adv Exp Med Biol. 2016; 884: 53-59.

40. Joens-Matre RR, Welk GJ, Calabro MA, Russell DW, Nicklay E, Hensley LD. Rural-urban differences in physical activity, physical fitness, and overweight prevalence of children. J. Rural Health 2008; 24: 49-54.

41. Kautiainen S, Koivisto AM, Koivusilta L, Lintonen T, Virtanen SM, Rimpela A. Sociodemographic factors and a secular trend of adolescent overweight in Finland. Int J Pediatr Obes. 2009; 4: 360-370.

42. Lindroth M, Lundqvist R, Lilja M, Eliasson M. Cardiovascular risk factors differ between rural and urban Sweden: The 2009 Northern Sweden MONICA cohort. BMC Pub Health 2014;14: 825-831.

43. Schröder PC, Li J, Wong GWK, Schaub B. The rural-urban enigma of allergy. What can we learn from studies around the world? Pediatr Allergy Immunol. 2015, 26: 95-102.

44. Tambalis KD, Panagiotakos DB, Sidossis LS. Greek children living in rural areas are heavier but fitter compared to their urban counterparts: a comparative, time-series (1997-2008) analysis. J Rural Health 2011; 27: $270-277$.

45. Wronka I, Suliga E, Pawlińska-Chmara R. Perceived and desired body weight among female university students in relation to BMI-based weight status and socio-economic factors. Ann Agric Environ Med. 2013; 20: 533-538. 